\title{
ANALISIS MUTU PELAYANAN PENDIDIKAN DENGAN MODEL SERVICE QUALITY
}

\section{Deviana}

Universitas Muhammadiyah Gresik devianaanaived@gmail.com

\section{Suyoto}

Universitas Muhammadiyah Gresik

kang.suyoto@umg.ac.id

\section{Mahjudin}

Universitas Muhammadiyah Gresik mahjudin@umg.ac.id

\section{Fery Adhy Permana}

Universitas Muhammadiyah Gresik fery.adhy01@gmail.com

\begin{abstract}
The quality of educational services needs to be considered in order to find out how much student satisfaction is as a user of educational services. The purpose of this study was to analyze the service quality of the Master of Management Study Program at the University of Muhammadiyah Gresik by using the Service Quality method (tangible, reliability, responsiveness, assurance, and empathy). This study uses a quantitative approach with an exploratory method where the population and sample are 55 active students of the Master of Management Study Program from the 2016 to 2019 class. The data analysis technique used is Service Quality by determining the value of the gap between perception and performance, making a ranking of the gap value. highest to lowest, and a Cartesius diagram. The results of the study stated that of the 5 dimensions of service quality, there are 2 dimensions that have the highest gap, namely tangible and responsiveness due to the incompatibility of students of the Master of Management Study Program, University of Muhammadiyah Gresik in getting proper service.
\end{abstract}

Keywords: Quality of Education Services; Service Quality; Diagram Cartesius

$\triangle$ Corresponding author:

Email Address :fery.adhy01@gmail.com(Gresik, Jawa Timur)

Received 9 Pebruari 2021, Accepted 11 Pebruari 2021, Published 22 Pebruari 2021

\section{PENDAHULUAN}

Peningkatan kualitas pengajaran di perguruan tinggi swasta mendapatkan perhatian yang besar, disamping tuntutan dari para pemakai jasa lulusan pendidikan tinggi yang makin meningkat. Masyarakat yang menggunakan jasa pendidikan tinggipun mulai menuntut sesuatu yang lebih, seiring dengan semakin mahalnya biaya pendidikan yang mereka bayarkan. Pada sektor pemerintah (pelayanan publik), negara mengatur standar pelayanan publik untuk mengukur kepuasan masyarakat terhadap pelayanan instansi pemerintah. Salah satu cara yang paling efektif dalam menjalin hubungan dengan mahasiswa adalah dengan memberikan pelayanan yang bisa memuaskan mahasiswa.

Setiap lembaga pendidikan berusaha untuk memberikan pelayanan yang berkualitas lebih tinggi dari pesaing secara konsisten. Kondisi kualitas pendidikan dipengaruhi oleh beberapa hal, yaitu: kurangnya efektivitas para tenaga pengajar (dosen) memberikan pelayanan dalam mengajar, pengembangan staf, 
ketidakcocokan pengelolaan gedung, kurangnya tersedianya sarana pendukung proses belajar mengajar, lingkungan belajar yang tidak kondusif, serta lemahnya perancangan kurikulum. Selain itu, faktor eksternal berupa keadaan ekonomi yang kurang baik juga mempengaruhi kualitas pendidikan. Pada proses belajar mengajar di lembaga pendidikan yang merupakan salah satu industri pelayanan, mahasiswa sebagai pelanggan internal selalu berharap untuk pelayanan pendidikan yang terbaik dari lembaga pendidikan yang mencakup tentang pelayanan, seperti: bukti langsung (tangible), kehandalan (reliability), daya tanggap (responsiveness), jaminan (assurance), dan empati (empathy). Dengan demikian perguruan tinggi akan memperhatikan kualitas jasa yang diberikan.

Gresik adalah salah satu kota pendidikan di Indonesia yang tercatat pada tahun 2020 dengan tujuh perguruan tingginya yang sampai saat ini menjadi kota pilihan calon mahasiswa. Sebagai salah satu institusi pendidikan dengan kurang lebih 55 mahasiswa program studi Magister Manajemen yang aktif berdasarkan data yang diperoleh dari Biro Administrasi Akademik (BAA) Universitas Muhammadiyah Gresik Jawa Timur. Didukung oleh tenaga pengajar yang kompeten di bidangnya dan sarana ruang yang memadai dengan ruang praktek yang lengkap dan nyaman, ruang kelas yang bersih dan lokasi yang strategis mudah dijangkau oleh mahasiswa.

Program studi Magister Manajemen Universitas Muhammadiyah Gresik, Jawa Timur memiliki komitmen untuk menghasilkan pendidikan yang bermutu. Universitas Muhammadiyah Gresik, Jawa Timur dalam mewujudkan komitmen menghasilkan pendidikan yang bermutu masih terus - menerus melakukan pembenahan dan perbaikan dalam menyajikan layanan pendidikan yang berkualitas yang baik serta memberi kepuasan pengguna layanan pendidikan. Namun, bukan hal mudah untuk mewujudkan komitmen tersebut, masih ada beberapa hal yang harus diperbaiki oleh Universitas Muhammadiyah Gresik Jawa Timur dalam menyajikan layanan pendidikan kepada penggunanya.

Berdasarkan hasil survey pendahuluan sebelum menentukan judul dalam penelitian ini, masih terdapat mahasiswa program studi Magister Manajemen, Universitas Muhammadiyah Gresik, Jawa Timur mengalami ketidakpuasan layanan pendidikan yang diinginkan mahasiswa sebagai pengguna layanan pendidikan. Terdapat ketidaksesuaian harapan yang diterima oleh mahasiswa magsiter manajemen dalam mutu layanan dan realitanya tidak sesuai dengan harapan yang diterima. Hasil ini telah disebar kepada 55 mahasiswa aktif program studi Magister Manajemen Universitas Muhammadiyah Gresik Jawa Timur di tahun 2020 mengenai mutu pelayanan pendidikan.

Pengertian kualitas layanan atau kualitas jasa berpusat pada upaya pemenuhan kebutuhan dan keinginan pelanggan serta ketepatan penyampaiannya untuk mengimbangi harapan pelanggan. Berikut ini beberapa definisi dari kualitas layanan menurut beberapa ahli: Menurut Wyckof dalam Tjiptono (2002), kualitas jasa adalah tingkat keunggulan yang diharapkan dan pengendalian atas tingkat keunggulan tersebut untuk memenuhi keinginan pelanggan. Definisi kualitas layanan atau kualitas jasa menurut Parasuraman (1988) merupakan refleksi persepsi evaluatif konsumen terhadap pelayanan yang diterima pada suatu waktu tertentu. Kualitas pelayanan ditentukan berdasarkan tingkat pentingnya pada dimensidimensi pelayanan.

Berdasarkan definisi kualitas layanan di atas dapat diketahui bahwa banyak interpretasi yang berbeda oleh masing-masing individu dalam konteks yang berlainan. Menurut Garvin (1988), perspektif kualitas dikelompokkan dalam 5 kelompok, sebagai berikut;

1. Transcendental approach, kualitas dipadang sebagai innate excellence, yakni sesuatu yang bisa dirasakan atau diketahui, namun sulit didefinisikan, dirumuskan atau dioperasionalisasikan.

2. Product based approach, mengasumsikan bahwa kualitas merupakan karakteristik/ atribut proyek yang dapat dikuantitatifkan dan dapat diukur.

3. User based approach, perspektif ini bersifat supply based dan lebih berfokus pada praktik-praktik perekayasaan dan pemanufakturan, serta mendefinisikan kualitas sebagai kesesuaian atau kecocokan dengan persyaratan.

4. Value based approach, memandang kualitas dari aspek nilai (value) dan harga (price).

\section{METODE PENELITIAN}


Penelitian ini merupakan penelitian eksploratif, yang menggali sebab-sebab terjadinya sesuatu (Suharsimi Arikunto, 2010). Penelitian ini berusaha untuk menggali informasi, menggambarkan, melukiskan atau mengetahui bagaimana penilaian mahasiswa pada dimensi tangible, reliability, responsiveness, assurance, dan empathy pada program studi Magister Manajemen, Universitas Muhammadiyah Gresik.

\subsection{Populasi dan Sampel}

Populasi sebagai wilayah generalisasi yang terdiri atas obyek/ subyek yang mempunyai kualitas dan karakteristik tertentu yang ditetapkan oleh peneliti untuk dipelajari dan kemudian ditarik kesimpulannya (Sugiyono, 2012). Sesuai dengan pendapat tersebut maka yang dijadikan populasi oleh peneliti adalah mahasiswa aktif magister manajemen dari angkatan 2016 - 2019 sejumlah 55 responden. Sampel dalam penelitian ini yakni semua responden mahasiswa aktif Magister Manajemen, Universitas Muhammadiyah Gresik angkatan 2016 - 2019. Hal ini dikarenakan jumlah sampel kurang dari 100, sehingga peneliti menggunakan sampling jenuh, dengan mengambil 55 responden guna meminimalisir kesalahan.

\section{Metode Analisis Data}

Pengukuran kualitas jasa dalam model SERVQUAL didasarkan pada skala multi-item yang dirancang untuk mengukur harapan dan persepsi pelanggan, serta gap di antara keduanya pada lima dimensi utama kualitas jasa (tangible, reliability, responsiveness, assurance, empathy). Kelima dimensi utama tersebut dijabarkan ke dalam masing-masing 27 variabel harapan dan variabel persepsi, yang disusun dalam pernyataan-pernyataan berdasarkan skala Likert, dari nilai 1 (Sangat Tidak Penting/ Sangat Tidak Puas) sampai nilai 5 (Sangat Penting; Sangat Puas). Skor SERVQUAL untuk setiap pasang Pernyataan, bagi masing-masing pelanggan dapat dihitung berdasarkan rumus berikut (Zeithaml, dkk, 1990)

Berikut langkah - langkah dalam metode analisis data, yakni;

1.Penentuan gap tiap indikator pada masingmasing dimensi.

2.Penentuan rangking secara keluruhan.

Setelah mengetahui hasil skor ServQual tiap indikator dimensi mutu layanan (tangible, reliability, responsiveness, assurance, empathy) di Program Studi Magister Manajemen Universitas Muhammadiyah Gresik, selanjutnya di rangking dari hasil skor terbesar hingga terkecil.

3. Penentuan prioritas perbaikan menggunakan Diagram Kartesius.

Diagram Kartesius merupakan metode yang dapat mengukur hubungan antara harapan/ kepentingan layanan yang ingin didapatkan oleh konsumen dengan kinerja layanan yang diterima oleh konsumen.

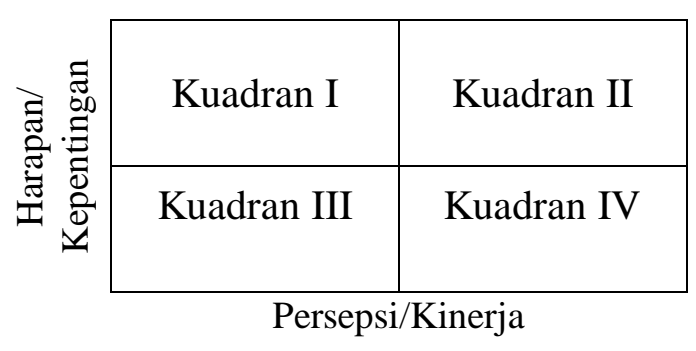

\section{Gambar 1. Diagram Kartesius}

Peneliti menganalisis adanya ketidak puasan terhadap mutu layanan di Universitas Muhammadiyah Gresik, khususnya di Program Studi Magister Manajemen, yang mana layanan yang diharapkan lebih rendah kualitas dibandingkan layanan yang diterima. Penelitian ini menggunakan metode "Servqual" dari pendapat Parasuraman (1988) dan Zeithaml, dkk (1990) yang memiliki 5 dimensi (tangible, reliability, responsiveness, assurance, dan empathy).

\section{HASIL DAN PEMBAHASAN}

Orientasi tangible yang jawaban positif dimana hal ini membawa konsekuensi pemaknaan pada nilai rata-rata hitung dimana nilai rata-rata hitung yang rendah dimaknai sebagai adanya penilaian yang tinggi. Lebih lanjut penilaian - penilaian tersebut dapat dilihat pada Tabel 1.

Tabel 1. Hasil Tanggapan Responden terhadap Dimensi Tangible

\begin{tabular}{|l|c|l|c|c|c|}
\hline \multirow{2}{*}{ Indikator } & \multirow{2}{*}{ No } & Item / Butir & \multicolumn{2}{|c|}{ Jawaban Responden } & \multirow{2}{*}{ GAP } \\
\cline { 3 - 5 } & 1 & $\begin{array}{l}\text { Penampilan } \\
\text { Petugas }\end{array}$ & 4,35 & 2.27 & 2.08 \\
\cline { 2 - 5 } & 2 & $\begin{array}{l}\text { Kenyaman- } \\
\text { an tempat }\end{array}$ & 4,38 & 2.33 & 2.05 \\
\cline { 2 - 5 } & 3 & Kemudahan & 4,47 & 2.29 & 2.18 \\
\cline { 2 - 5 } & 4 & $\begin{array}{l}\text { Kedisiplina } \\
\text { n petugas }\end{array}$ & 4,35 & 2.44 & 1.91 \\
\cline { 2 - 5 } & 5 & Kemudahan & 4,40 & 2.51 & 1.89 \\
\hline
\end{tabular}




\begin{tabular}{|c|c|l|c|c|c|}
\hline \multirow{3}{*}{ Indikator } & \multirow{2}{*}{ No } & Item / Butir & \multicolumn{2}{|c|}{ Jawaban Responden } & \multirow{2}{*}{ GAP } \\
\cline { 2 - 4 } & & akses & Harapan & Realita & \\
\cline { 2 - 4 } & 6 & $\begin{array}{l}\text { Penggunaa } \\
\text { n alat bantu }\end{array}$ & 4,62 & 2.44 & 2.18 \\
\hline \multicolumn{3}{|l|}{ Mean Dimensi Tangible } & & 2,04 \\
\hline
\end{tabular}

Sumber: Data Diolah (2020)

Orientasi kehandalan (Reliabilty) yang jawaban positif dimana hal ini membawa konsekuensi pemaknaan pada nilai rata-rata hitung dimana nilai rata - rata hitung yang rendah dimaknai sebagai adanya penilaian yang tinggi. Lebih lanjut penilaian-penilaian tersebut dapat dilihat pada Tabel 2.

Tabel 2. Hasil Tanggapan Responden Terhadap Dimensi Reliability

\begin{tabular}{|c|c|c|c|c|c|}
\hline \multirow{2}{*}{$\begin{array}{l}\text { Indi } \\
\text { kator }\end{array}$} & \multirow{2}{*}{ No } & \multirow{2}{*}{ Item / Butir } & \multicolumn{2}{|c|}{ Jawaban Responden } & \multirow{2}{*}{ GAP } \\
\hline & & & Harapan & Realita & \\
\hline \multirow{6}{*}{$\begin{array}{l}\text { Relia } \\
\text { bility }\end{array}$} & 1 & $\begin{array}{l}\text { Kecermatan } \\
\text { petugas }\end{array}$ & 4,31 & 2.25 & 2.06 \\
\hline & 2 & $\begin{array}{l}\text { Memiliki } \\
\text { standar }\end{array}$ & 4,38 & 2.44 & 1.94 \\
\hline & 3 & $\begin{array}{l}\text { Kemampua } \\
\mathrm{n}\end{array}$ & 4,45 & 2.31 & 2.14 \\
\hline & 4 & Keahlian. & 4,31 & 2.45 & 1.86 \\
\hline & 5 & $\begin{array}{l}\text { Keahlian } \\
\text { daring }\end{array}$ & 4,45 & 2.33 & 2.12 \\
\hline & 6 & $\begin{array}{l}\text { pelayanan } \\
\text { bimbingan } \\
\text { tesis }\end{array}$ & 4,25 & 2.49 & 1.76 \\
\hline \multicolumn{5}{|c|}{ Mean dimensi Reliability } & 1,98 \\
\hline
\end{tabular}

Sumber: Data Diolah (2020)

Orientasi daya tanggap (Responsiveness) yang jawaban positif dimana hal ini membawa konsekuensi pemaknaan pada nilai rata-rata hitung dimana nilai rata - rata hitung yang rendah dimaknai sebagai adanya penialaian yang tinggi. Lebih lanjut tanggapan dilihat pada Tabel 3 .

Tabel 3. Hasil Tanggapan Responden Terhadap Dimensi Responsiveness

\begin{tabular}{|l|c|l|c|c|c|}
\hline \multirow{2}{*}{$\begin{array}{l}\text { Indi } \\
\text { kator }\end{array}$} & No & Item / Butir & \multicolumn{2}{|c|}{ Jawaban Responden } & \multirow{2}{*}{ GAP } \\
\cline { 3 - 5 } & 1 & Merespon & 4.25 & 2.16 & 2.09 \\
\cline { 2 - 5 } & 2 & $\begin{array}{l}\text { Pelayanan } \\
\text { dengan cepat }\end{array}$ & 4.36 & 2.29 & 2.07 \\
\cline { 2 - 4 } $\begin{array}{l}\text { Resp } \\
\text { onsiv } \\
\text { eness }\end{array}$ & 3 & $\begin{array}{l}\text { Pelayanan } \\
\text { dengan tepat }\end{array}$ & 4.44 & 2.33 & 2.11 \\
\cline { 2 - 4 } & 4 & $\begin{array}{l}\text { pelayanan } \\
\text { dengan cermat }\end{array}$ & 4.35 & 2.55 & 1.8 \\
\cline { 2 - 4 } & 5 & $\begin{array}{l}\text { pelayanan } \\
\text { dengan waktu } \\
\text { yang tepat }\end{array}$ & 4.47 & 2.44 & 2.03 \\
\cline { 2 - 4 } & 6 & $\begin{array}{l}\text { Semua keluhan } \\
\text { pelanggan } \\
\text { direspon }\end{array}$ & 4.40 & 2.20 & 2.2 \\
\hline \multicolumn{3}{|l|}{ Mean dimensi Responsiveness } & 2.05 \\
\hline
\end{tabular}

Sumber: Data Diolah (2020)
Orientasi Jaminan (Assurance) yang jawaban positif dimana hal ini membawa konsekuensi pemaknaan pada nilai rata-rata hitung dimana nilai rata-rata hitung yang rendah dimaknai sebagai adanya penialaian yang tinggi. Lebih lanjut penilaian-penilaian tersebut dapat dilihat pada Tabel 4.

Tabel 4. Hasil Tanggapan Responden Terhadap dimensi Assurance

\begin{tabular}{|c|c|c|c|c|c|}
\hline \multirow[t]{2}{*}{ Indikator } & \multirow{2}{*}{ No } & \multirow{2}{*}{ Item / Butir } & \multicolumn{2}{|c|}{ Jawaban Responden } & \multirow{2}{*}{ GAP } \\
\hline & & & Harapan & Realita & \\
\hline \multirow{4}{*}{$\begin{array}{l}\text { Assuran } \\
\text { ce }\end{array}$} & 1 & $\begin{array}{l}\text { jaminan } \\
\text { tepat waktu }\end{array}$ & 4.31 & 2.27 & 2.04 \\
\hline & 2 & jaminan biaya & 4.36 & 2.55 & 1.81 \\
\hline & 3 & $\begin{array}{l}\text { jaminan } \\
\text { legalitas }\end{array}$ & 4.31 & 2.25 & 2.06 \\
\hline & 4 & $\begin{array}{l}\text { jaminan } \\
\text { kepastian } \\
\text { biaya }\end{array}$ & 4.45 & 2.44 & 2.01 \\
\hline \multicolumn{5}{|c|}{ Mean dimensi Assurance } & 1,98 \\
\hline
\end{tabular}

Sumber: Data Diolah (2020)

Orientasi perhatian (Empathy) yang jawaban positif dalam penelitian dimana hal ini membawa konsekuensi pemaknaan pada nilai rata-rata hitung dimana nilai rata-rata hitung yang rendah dimaknai sebagai adanya penialaian yang tinggi. Lebih lanjut penilaianpenilaian tersebut dapat dilihat pada Tabel 5.

Tabel 5. Hasil Tanggapan Responden Terhadap Dimensi Empathy

\begin{tabular}{|l|l|l|c|c|c|}
\hline \multirow{5}{*}{ Indikator } & \multirow{2}{*}{ No } & Item / Butir & \multicolumn{2}{|c|}{ Jawaban Responden } & \multirow{2}{*}{ GAP } \\
\cline { 3 - 5 } & 1 & $\begin{array}{l}\text { dahulukan } \\
\text { kepentingan } \\
\text { pemohon }\end{array}$ & 4.35 & 2.25 & 2.1 \\
\cline { 2 - 5 } Empathy & 2 & sikap ramah & 4.35 & 2.27 & 2.08 \\
\cline { 2 - 5 } & 3 & $\begin{array}{l}\text { Penuh } \\
\text { perhatian }\end{array}$ & 4.45 & 2.36 & 2.09 \\
\cline { 2 - 5 } & 4 & $\begin{array}{l}\text { tidak } \\
\text { diskriminatif }\end{array}$ & 4.31 & 2.42 & 1.89 \\
\cline { 2 - 5 } & 5 & $\begin{array}{l}\text { menghargai } \\
\text { setiap } \\
\text { pelanggan }\end{array}$ & 4.42 & 2.49 & 1.93 \\
\hline \multicolumn{7}{|l}{ Mean dimensi Empathy } & & \\
\hline
\end{tabular}

Sumber: Data Diolah (2020)

Dapat diketahui bahwa terdapat 18 indikator yang memiliki Gap di atas 2,00 dan 9 indikator yang memiliki Gap di bawah 2,00. Sembilan indikator tersebut yang memiliki Gap dibawah 2,00 tidak perlu dibahas dikarenakan tidak terlalu penting, di mana responden tidak terlalu mengeluhkan 9 indikator tersebut. Berdasarkan rangking tersebut yang paling jauh dari harapan responden terhadap realita mutu layanan di Program Studi Magister Manajemen pada dimensi responsiveness dan tangible. 
Gambar 2. menunjukkan bahwa diagram kartesius tersebut memiliki titik ABCD. Titik B terletak pada kuadran I, titik A terletak pada kuadran II, dan titik C D terletak pada kuadran III, sehingga membentuk posisi kuadran Z.

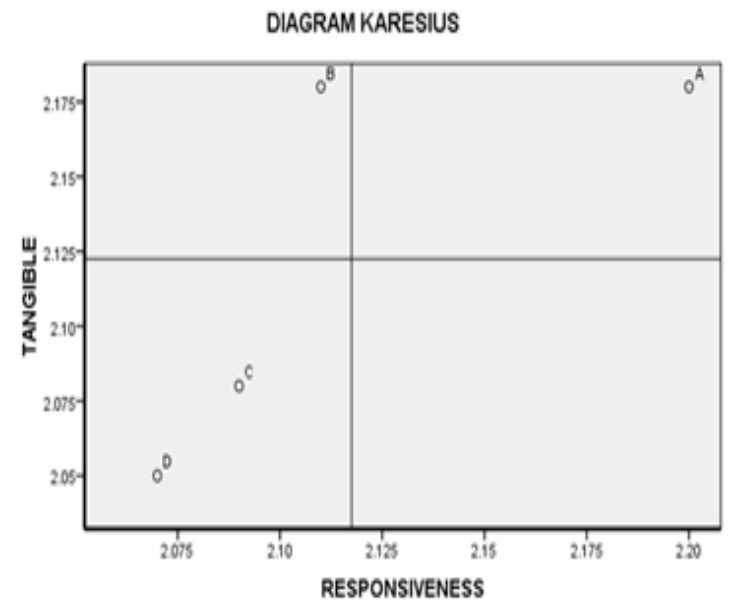

Gambar 2. Diagram Kartesius

Titik yang menjadi prioritas dalam penelitian yakni A dan B, sedangkan titik $\mathrm{C}$ dan $\mathrm{D}$ tidak perlu diperhatikan secara serius oleh manajemen karena tidak dianggap penting oleh pelanggan.

Titik A dan B menyatakan pernyataan pernyataan prioritas dalam penelitian karena tidak sesuai harapan bagi mahasiswa Magister Manajemen. Terdapat selisih sangat besar dengan realita titik A sebagai dimensi responsiveness memiliki nilai Gap yakni 2,20 dan titik B sebagai dimensi tangible memiliki nilai Gap yakni 2,18. Selisih Gap pada titik A (responsiveness) dan B sangatlah kecil yakni 0,02 , sehingga dapat dijadikan bahwa sebagai kedua titik tersebut (A dan B) merupakan yang perlu diperbaiki oleh manajemen Universitas Muhammadiyah Gresik

\section{PEMBAHASAN}

Berdasarkan perhitungan dengan menggunakan koesioner penilaian mutu layanan dengan menggunakan metode service quality, dapat diketahui bahwa terdapat 2 dimensi yang memiliki selisih gap yang tinggi dari perhitungan penilaian harapan dengan penilaian realita. Dimensi tersebut yakni dimensi tangible dan responsiveness. Kedua dimensi tersebut memiliki gap yang tinggi karena terdapat ketidaksesuaian mahasiswa mendapatkan layanan yang di bentuk oleh dimensi tangible dan dimensi responsiveness. Dengan kondisi seperti ini Magister Manajemen Universitas Muhammadiyah Gresik belum memberikan mutu pelayanan yang maksimal dalam bentuk tangible dan responsiveness bagi mahasiswa Magister Manajemen.

\section{SIMPULAN}

Kedua dimensi yang memiliki gap tertinggi dikarenakan adanya ketidak sesuaian mahasiswa mendapatkan layanan yang dalam bentuk dimensi tangiblet dan dimensi responsiveness. Magister Manajemen, Universitas Muhammadiyah Gresik belum memberikan mutu pelayanan yang maksimal dalam bentuk responsiveness dikarenakan kurangnya jumlah sumber daya manusia/ karyawan baik jumlah tenaga admin maupun jumlah dosen yang memiliki jabatan fungsional, sehingga tidak optimal dalam menghandle secara sigap segala keluhan mahasiswa Magister Manajemen. Magister Manajemen Univeritas Muhammadiyah Gresik belum memberikan mutu pelayanan yang maksimal juga dalam bentuk tangible dikarenakan birokrasi yang terlalu rumit untuk mahasiswa Magister Manajemen yang mayoritas pekerja.

\section{DAFTAR PUSTAKA}

Arikunto, S. 2010. Prosedur Penelitian Suatu Pendekatan Praktik. Jakarta : Rineka Cipta.

Azan, Khairul, Meirawan, Danny, \& Sutarsih, Cicih. 2015. Mutu Layanan Akademik. Jurnal Adminitrasi Pendidikan Vol. XXVII No. 1 April 2015.

Bounds, Greg, et. al. 1994. Beyonds Total Quality Management : Toward The Emerging Paradigm. New York : Mc Graw-Hill International, Inc.

Brady, M., \& Cronin, J. 2001. Some New Though On Conceptualizing Perceived Quality: A Hierarchial Approach, Journal of Marketing, 65, 34-49.

Garvin, David A. 1988. Managing Quality. New York : The New York Press.

Gasperz, Vincent. 1997. Manajemen Kualitas Dalam Industri Jasa. Jakarta: PT. Gramedia Pustaka Utama.

Hasan, Iqbal. 2005. Pokok-Pokok Materi Statistik 2. Cetakan 3. Jakarta : Bumi Aksara.

Hidayat, Rofiq. 2020. Implementasi Servqual Dalam Meningkatkan Mutu Layanan 
Pada Manajemen Pemasaran Pendidikan. JIEMAN ; Journal of Islamic Educational Manajement. Vol. 1, No. 2, Juni 2020.

Hurriyati, Ratih. 2005. Bauran Pemasaran dan Loyalitas Konsumen. Bandung : Alfabeta.

Jasfar, Farida. 2012. Teori dan Aplikasi Sembilan Kunci Keberhasilan Bisnis Jasa: Sumber Daya Manusia, Inovasi, dan Kepuasan Pelanggan. Jakarta : Penerbit Salemba Empat.

Khikmawati, Emy, Wibowo, H, \& Farla, Z. 2019. Analisis Mutu Layanan Instalasi Rawat Inap Menggunakan Metode Servqual-Fuzzy Dalam Upaya Meningkatkan Mutu Layanan Jasa Kesehatan di RS PBA Bandar Lampung. Jurnal Hasil Penelitian dan Karya Ilmiah dalam Bidang Teknik Industri. Vol. 5, No.1. 2019.

Lovelock, Christoper. 1999. Product Plus : How Product + Service $=$ Competitive Advantage. New York : Mc Graw-Hill.

Lupiyoadi, Rambat. 2014. Manajemen Pemasaran Jasa Edisi 3. Jakarta: Salemba Empat.

Mudie \& Pirrie. 2006. Services Marketing Management. Third edition. Elsevier Ltd.

Nazir, Moh. 2005. Metode Penelitian. Jakarta : Ghalia Indonesia.

Parasuraman, et.al. 1988. Konsep dan Teknik Pengukuran Kualitas Produk Jasa, Kajian Bisnis dan Manajemen. Vol. 4, No. 1, Hal. 55-56.

Purba, Ratih.P.K \& Sailan, M.Z. 2020. Analisis Kualitas Pelayanan di Program Studi Farmasi Poltekkes Kemenkes Pangkalpinang Menggunakan Metode Servqual. Jurnal Kesehatan Poltekkes Kemenkes RI Pangkalpinang Vol. 8, No. 1 Juni 2020.

Setyanto, N.W, Rahman, Arif, \& Trisagita, A. 2013. Penerapan Metode Delphi dan Servqual untuk Perbaikan Mutu Pelayanan (Studi Kasus Program Studi Teknik Industri Universitas Brawijaya). Jurnal Seminar Nasional Terpadu Keilmuan Teknik Industri. 16 Maret 2013. Malang : Universitas Brawijaya SMG-4-1.

Schiffman, L.G. \& L.L, Kanuk. 1987. Costumer Behaviour. New Jersey : Prentice Hall Incorporation.

Sugiyono. 2012. Metode Penelitian Kuantitatif Kualitatif dan R\&D. Bandung : Alfabeta.
Sugiyono. 2013. Metode Penelitian Pendidikan Pendekatan Kuantitatif, Kualitatif, dan R\&D. Bandung : Alfabeta.

Sumarni, Murti. 2002. Manajemen Pemasaran Bank. Yogyakarta: Liberti.

Tjiptono, Fandy. 2002. Manajemen Jasa. Cetakan ke 2. Yogyakarta : Penerbit ANDI.

Tjiptono, Fandy. 2004. Manajemen Jasa. Cetakan ke 3. Yogyakarta : Penerbit ANDI.

Tjiptono, Fandy \& Chandra, Gregorius. 2005. Service, Quality, and Satisfaction. Edisi 3. Yogyakarta : Penerbit Andi.

Tjiptono, Fandy \& Chandra, Gregorius. 2012. Service, Quality, and Satisfaction. Edisi 3. Yogyakarta : Penerbit Andi.

Zeithaml, dkk. 1990. Service Marketing Integrating Customer Focus Across The Firm. New York : McGraw-Hill Companies. 